\author{
Aldona PODGÓRNIAK-KRZYKACZ, PhD \\ Faculty of Economics and Sociology, University of Lodz \\ e-mail: aldona.podgorniak@uni.lodz.pl \\ ORCID: 0000-0003-0029-0418 \\ Justyna PRZYWOJSKA, PhD \\ Faculty of Economics and Sociology, University of Lodz \\ e-mail: justyna.przywojska@uni.lodz.pl \\ ORCID: 0000-0002-1125-2225
}

DOI: $10.15290 /$ oes.2019.04.98.10

\title{
THE CHALLENGES OF LOCAL DEVELOPMENT AND THE PRIORITIES OF MAYORS AND PRESIDENTS OF POLISH CITIES - CONVERGENCE OR DISSONANCE? ${ }^{1}$
}

\begin{abstract}
Summary
Purpose - The aim of the paper is to identify the key urban development challenges in Poland and to verify the opinions of Polish mayors about them.

Research method - The research used the quantitative method in the form of a survey conducted among 460 leaders of Polish cities together with desk research analysis including the data from the official statistics and reports from 2014-2018.

Results - It was established that in their political agendas mayors include the postulates presenting a traditional approach to sustainable development, which is directed at the economy, society and the environment, but underestimates environmental issues. They are not aware of the new development challenges, but focus on the traditional, infrastructural and economic priorities.

Originality / value - For the first time in Poland the results of comprehensive research on the priorities of city development that were declared by mayors are presented. They include the latest determinants for sustainable development, such as: the technological revolution, the management of ethnical and cultural diversity in urban communities, the depopulation and degradation of city centres and also circular economics. The findings of the research fill an existing gap in knowledge about the city leaders' points of view on the challenges facing modern cities and thus define a political climate for the implementation of the principles of sustainable development.
\end{abstract}

Key words: political priority, development challenge, sustainable development, cities

JEL Classification: R580, Q560, R500

${ }^{1}$ Article received on 3 April 2019, accepted on 9 September 2019. 


\section{Introduction}

Due to the rapid urbanization and urban boom on a worldwide scale, an essential global challenge has been to guarantee a proper standard of living for all social groups and minorities residing in cities. To achieve this requires not only a developed material infrastructure, urban economy and favorable labor markets but also support for the poorest people. The preferences of city inhabitants to a considerably larger degree include access to green and recreational areas, availability of high quality natural resources, safe and open public spaces, modern solutions facilitating the transfer of people, goods and information as well as advanced and creative public institutions. Thestrive for sustainable development that takes new technologies and social fairness into consideration has become the main objective in the development of cities.

The urgent need to strive for sustainable development compels the radical change of the paradigm related to the way of planning, financing, developing, administrating and managing cities [New Urban Agenda, 2017, pp. 23-25], and thus sets new requirements for the political leaders governing them. In accordance with the concept of urban governance the most desired values include: an attitude of entrepreneurship, efficient aspiration for resources and their integration, the ability to coordinate undertakings (taking into consideration diverse interests) or the formation of institutional and territorial relations [Podgórniak-Krzykacz, 2016, pp. 25-26]. The concept of sustainable governance emphasizes the fact that cooperation practices are essential in theattempt for the successful achievement of sustainable development [Meadowcroft et al., 2005, p. 5]. In the context of climate change there is a requirement concerning the capability of generating flexible and sustainable management instruments for reaction, adaptation and solution of environmental and ecological problems [Mendizabala et al., 2018, p. 411]. The management of urban transformation, which is realized in order to increase the resistance of cities and their sustainable development and organisation in preparing them for the global challenges. requires a political leader with a clearly defined vision, motivation, involvement and trust [Mendizabala et al., 2018, pp. 411-16]. Undoubtedly, the starting point is the awareness that urban politicians face new challenges the consequences that they entail.

Additionally, the mayors of Polish cities are facing the difficult challenges connected with ensuring proper conditions for the improvement of both material and environmental positions of the inhabitants, development of social relations as well as social inclusion. Do Polish cities stand a chance of becoming cities which develop in a sustainable way? Are their managers aware of the present challenges for sustainable development? The paper constitutes an attempt to answer these questions. Its main aim is to identify the key development challenges for cities in Poland and to verify the views and opinions that the mayors of Polish cities have. The following hypothesis has been made: the territorial authorities of Polish cities are not aware of the new development challenges (such as: the technological revolution and smart city, the management of ethnical and cultural diversity in urban 
societies, revitalization and circular economics), but they focus on the traditional priorities such as infrastructural and economic ones.

The first part of the paper includes the characteristic of the main development challenges listed in the National Urban Policy, while using data from public statistics and the report results of research conducted in the years 2014-2018, devoted to the development problems in Polish cities. The subsequent part of the paper presents an evaluation of the importance of 11 development challenges made by the mayors and presidents of Polish cities that performed their functions in the years 2014-2018 and the ranking of the most important priorities in the policy of the city's development. The source of data constituted the results of the quantitative research conducted using the survey method among 460 mayors and presidents of Polish cities.

\section{The key challenges for the development of Polish cities}

The socio-economic image of Polish cities specified in the National Urban Policy lists the following factors among the key challenges determining the local development in cities: environmental pollution and the decreasing amount of natural resources, the ageing and depopulation of society, uncontrolled urban sprawl, social inequalities and the degradation of the central city areas, the digitalization and expansion of information and communication technologies, cooperation and the connection of the resources possessed by various interested parties of the urban policy [Krajowa Polityka ..., 2015, pp. 17-98].

A particularly important challenge for Polish cities is the degradation of their centres [Przywojska, 2016]. In 2016, the total area of degraded areas in 414 municipalities amounted to more than 715,000 ha, which on average constituted $14.4 \%$ of the area of these municipalities. In total, these areas were inhabited by 4 million people $(30 \%$ of the inhabitants of these municipalities) [Dane statystyczne $z$ zakresu ..., 2017]. The limitation of the mass scale degradation of Polish cities requires substantial revitalization changes and a strategic approach to this process.

Another source of challenge for development are the demographic processes involved. Large Polish cities are becoming smaller, which is a characteristic feature of post-socialist countries of Eastern Europe [Haase, 2013, pp. 32-33]. In particular, the situation of reduced population numbers in cities with more than 200.000 inhabitants (from the level of 8.3 million in 2000 to 7.6 million in 2017 [Rocznik demograficzny, 2018, p. 88]). The forecasts predict that until 2050 there will have been a reduction in the present 12.6 million inhabitants of cities with citizenship by a further 3 million inhabitants, while in some agglomerations the decrease will be partially reduced by the reverse processes of the suburbanization of the suburban areas (Warszawa, Trójmiasto, Poznań, Wrocław, Kraków, Lublin, Bydgoszcz/Toruń) [Śleszyński, 2018, pp. 226-227].

Additionally, in Polish cities it can be observed that unfavorable changes in the population structure in terms of age, which is visible in the systematic increase in the number of elderly people exist. In 2016 there were 37.7 persons in post-production 
age per 100 persons in production age in cities; by 2050 this number is likely to increase to as many as 57 [Rocznik demograficzny, 2018, p. 143, 170]. The rate of city inhabitants aged older than 65 increased from $12.3 \%$ in 2000 to a level of $18.5 \%$ in 2017 [Rocznik demograficzny, 2018, pp. 135-136]. The ageing of society is additionally reinforced by the processes of emigration of young people, which in particularly affects small and medium-sized cities [Rocznik demograficzny, 2018, p. 412]. The less favorable effects of emigration for the demographic structure of a cities' population are to a certain degree reduced by the processes of immigration, the intensification of which has been observed in Poland since 2013. Immigration is mostly linked to earning potential and includes the influx of people from the Ukraine. It is projected that the approximate number of immigrants in Poland amounts to approximately 1 million people [Nowe priorytety ..., 2018]. Due to a more developed labour market in large cities, the concentration of immigrants can mostly be observed there, as the consequence of which the authorities are facing the important challenge of the minority integration in local communities.

The poverty of Polish people in terms of disposable income remains an essential social problem. In 2018 this issue affected 5\% of households in cities with more than 500.000 inhabitants, while in cities with less than 20.000 inhabitants - almost $13 \%$ of the resisents lived in poverty. In turn, in large cities with more than 500.000 inhabitants we can see the largest disparity in income levels [Różne oblicza ubóstwa, 2018, p. 3].

The problem of air pollution needs to be addressed and requires a prompt solution. The exposure of the inhabitants of Polish cities to pollution in the form of particulates of PM2.5 and PM10 is the highest in Europe [www 1]. The European Environment Agency states that the air pollution in Poland causes the death of 45.000 people each year [www 2]. Owing to the accumulation of the sources of low emission and industrial sources as well as due to increased motor traffic the highest levels of pollution are observed in cities which are located in the Southern and central parts of Poland.

In the largest Polish cities a concentration of business activity, high quality of human capital and innovations is present. However, in comparison the level of their competitiveness is much lower than in the cities of Western Europe. They are characterized by lower levels of entrepreneurship, the effectiveness of using qualified labour force or the companies' ability to create and maintain working positions [Szczech-Pietkiewicz, 2012, pp. 128-150]. In a competitiveness ranking which included 159 European cities with more than 100,000 inhabitants from 26 countries, Polish cities occupied remote positions: 25 (Warsaw), while 13 cities were listed in the positions from 100 to 200 [Sáez et al., 2017, pp. 479-496].

Polish cities are to an increasing degree implementing the trends from the sphere of smart cities. These include initiatives such as: low-emission economy, smart transportation systems and e-administration [Sikora-Fernandez, 2018, pp. 52-59]. However, there is no advanced approach to the implementation of advanced technologies in city management. Only 8 among 16 voivodeship cities have the potential to transform into smart cities, whereas others are characterized by major 
potential only in certain spheres (e.g. Lódź in the domain of smart environment) [Sikora-Fernandez, 2018, pp. 52-59].

The ability to efficiently respond to development challenges can to a larger degree be determined by the professionalism of urban management. The activity of self-government authorities and the administration they are responsible for displays certain weaknesses. Polish cities are only to a small degree prepared to shape the economic and social relations that will be based on partnership and their ability to respond competently to the needs of entrepreneurs is inadequate [Marks-Bielska et al., 2017, pp. 99-102]. The major problems in the functioning of self-government officesoccur also in spheres such as: the implementation of electronic administration and the digitalization of offices, audit and control, planning and the realization of infrastructure investments and the formation of relations with inhabitants [Trutkowski, 2016, pp. 19-73].

On the basis of the analysis of statistical data and reports concerning the research one may state clearly that urban development challenges occurring in Poland concern all the dimensions of sustainable development and are to an increasing degree determined by smart solutions that imply fairness and social, economic and environmental cohesion.

\section{The research results and discussion}

This part of the paper presents the results of the research relating to the importance of development challenges from the perspective of the executive organs of Polish cities. The research was conducted in 2017, and the electronic survey was addressed at all municipalities in Poland. The research was participated in by $50 \%$ of the population - 1236 municipalities. Owing to the problem mentioned in the introduction, this paper presents a detailed analyses of the results concerning both urban and rural municipalities. The questionnaire was elaborated on the basis of the subject literature, especially taking into consideration the assumptions of the European opinion poll which was conducted among self-government leaders and realized within the Polleader network [Magnier et al., 2006; Cabria et al., 2018]. As part of the analysis 11 development challenges were selected (chart 1). The assessment of their importance was prioritized by the respondents (city mayors and presidents or officials representing them), using the Likert scale from 1 to 5 (1 being very low, and 5 being a very high priority). Additionally, the respondents selected one challenge they considered to be the most important. On this basis the ranking of priorities of a cities' development was elaborated. The respondents represented 460 municipalities comprising a city in relation to their territory. The sample structure possesses similarities to the population of municipalities of this category (the index of structures' similarity owing to the unit type amounts to $92.5 \%$, but urban and rural municipalities are slightly less visible). A detailed presentation of the results in terms of the municipality sample is shown in table 1. 
TABLE 1

The structure of the analyzed municipalities in accordance with the municipality type

\begin{tabular}{|l|c|c|}
\hline & $\mathbf{n}$ & $\mathbf{\%}$ \\
\hline In total & 460 & 100.0 \\
\hline Cities with country rights (CCR) & 42 & 9.1 \\
Urban municipalities (UM) & 144 & 31.3 \\
Urban and rural municipalities (URM) & 274 & 59.6 \\
\hline
\end{tabular}

Source: own elaboration.

The opinions of the respondents regarding the evaluation of the importance of challenges for the development of Polish cities are presented on chart 1. It implies that the most important issues are connected with stimulating economic growth and attracting investors and with improving the infrastructural base and social policy (high and very high priority were mentioned by more than $80 \%$ respondents). As regards to the revitalization of degraded areas and the environment protection, the evaluations are diverse - ranging from high to a very high priority. The challenge of solving problems of a political and administrative nature, received high marks from city mayors and presidents rather than the very high ones. The structure of evaluations is different in the closed circle where (apart from the dominating high priority) a large group of respondents regarded it as not so important. The last three challenges (the implementation of smart solutions, the reaction to the technological revolution and the integration of minorities) were considered by the respondents as less important. It is necessary to assess the very small importance of the priority connected to the need to integrate minorities in urban communities in the face of intense economic immigration to Poland from the Ukraine.

The ranking of development priorities (chart 2), which was elaborated on the basis of the respondents' choice of the most important challenges among the 11 which were analyzed, confirms the pro-economic orientation of political agendas of urban leaders. The hierarchy of development priorities can possibly be attributed to the development of the local economy. Interestingly, the development of infrastructure occupied third position and gives way to the development of social policy. The protection of the natural environment, as the most important priority for city development, was cited by only $2.8 \%$ of respondents. The idea of circular economics, smart city and revitalization by means of investments in human capital and technological revolution were assessed in a negative way. The integration of immigrants was not included in the analyzed ranking, which signifies that none of the respondents considered it most crucial for sustainable and consistent city development. 


\section{CHART 1 \\ An evaluation of the importance of challenges for the development of cities according to mayors and presidents $(\mathrm{N}=460)($ in \%)}

The improvement of the integration of minorities, e.g. ethnical, religious or cultural ones and emphasizing the role of diversity and tolerance in a local community

The reaction to global trends and technological revolution

The implementation of the concept of smart city in a municipality

The shaping of municipal economy in closed circulation (the development of circular economics)

The solution of political and administrative problems e.g. in order to improve the relations with citizens, better or more effective public services, combat corruption, etc.

The revitalization of degraded areas by means of investments in human and social capital of inhabitants

The natural environment protection and both secure and responsible usage of natural resources

The revitalization of degraded areas by means of the modernization and renovations of buildings and infrastructure

The development of social policy in order to ensure proper housing conditions, health care, education, culture and concern for the needs of weaker social groups (elderly people, ...)

The stimulation of economic growth and employment, the attraction of investors and the creation of investment offers

The improvement of the local infrastructure, communication and transport.

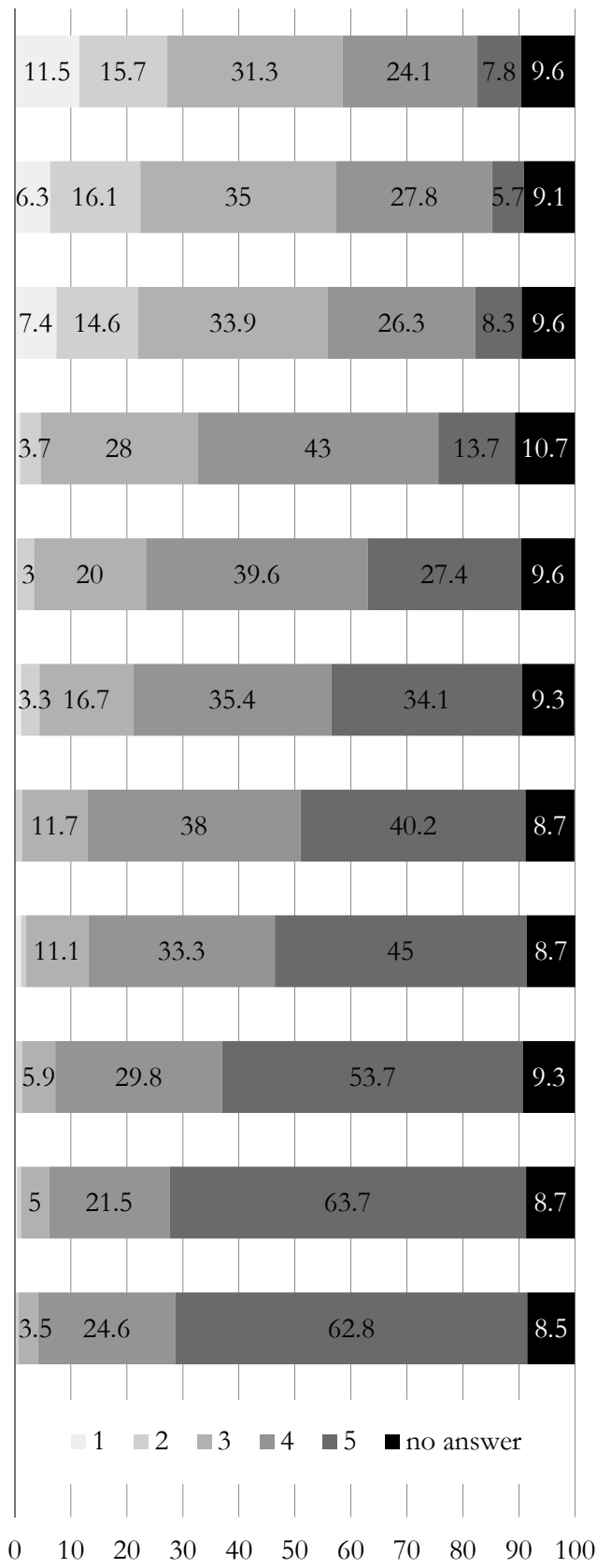

Source: own elaboration. 
CHART 2

The ranking of priorities of city development in the opinion of urban political leaders (city mayors and presidents) $(\mathrm{N}=460)($ in $\%)$

The revitalization of degraded areas by means of investments in human and social capital of inhabitants

The implementation of the concept of smart city in a municipality

The shaping of municipal economy in closed circulation

The solution of political and administrative problems

The natural environment protection and both secure and responsible usage of natural resources

The revitalization of degraded areas by means of modernization and renovations of buildings and infrastructure

The improvement of the local infrastructure, communication and transport

The development of social policy

The stimulation of economic growth and employment, the attraction of investors and the creation of investment offers

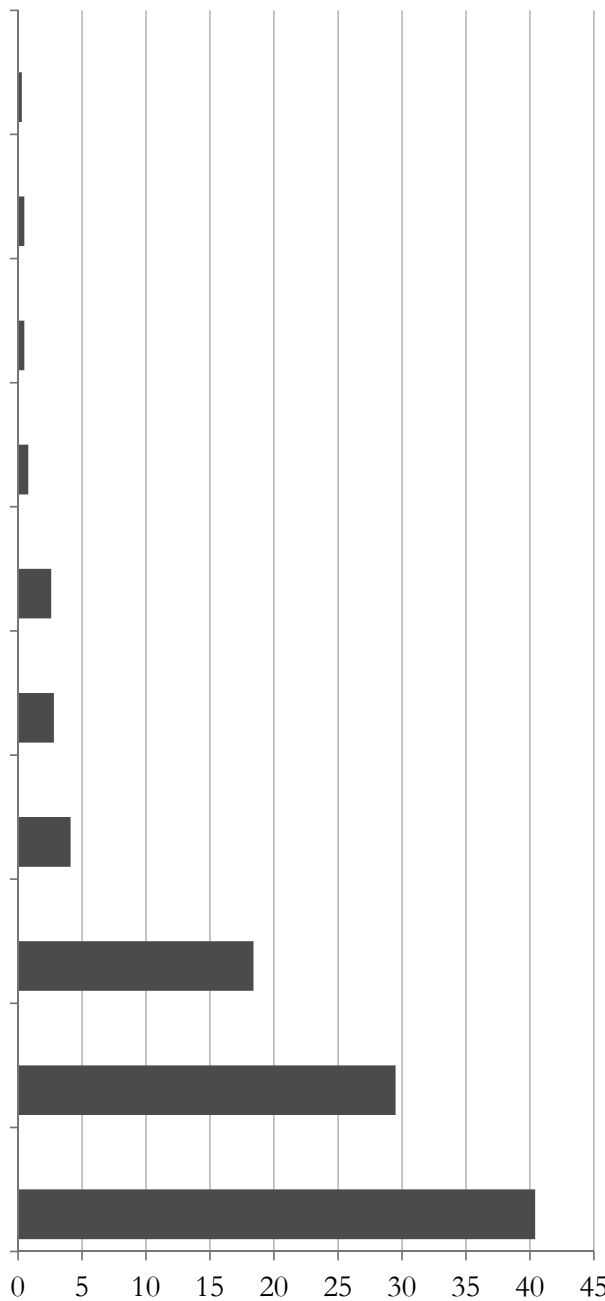

Source: own elaboration. 
CHART 3

The ranking of development priorities in accordance with the municipality types $(\mathrm{N}=460)$, (in \%)

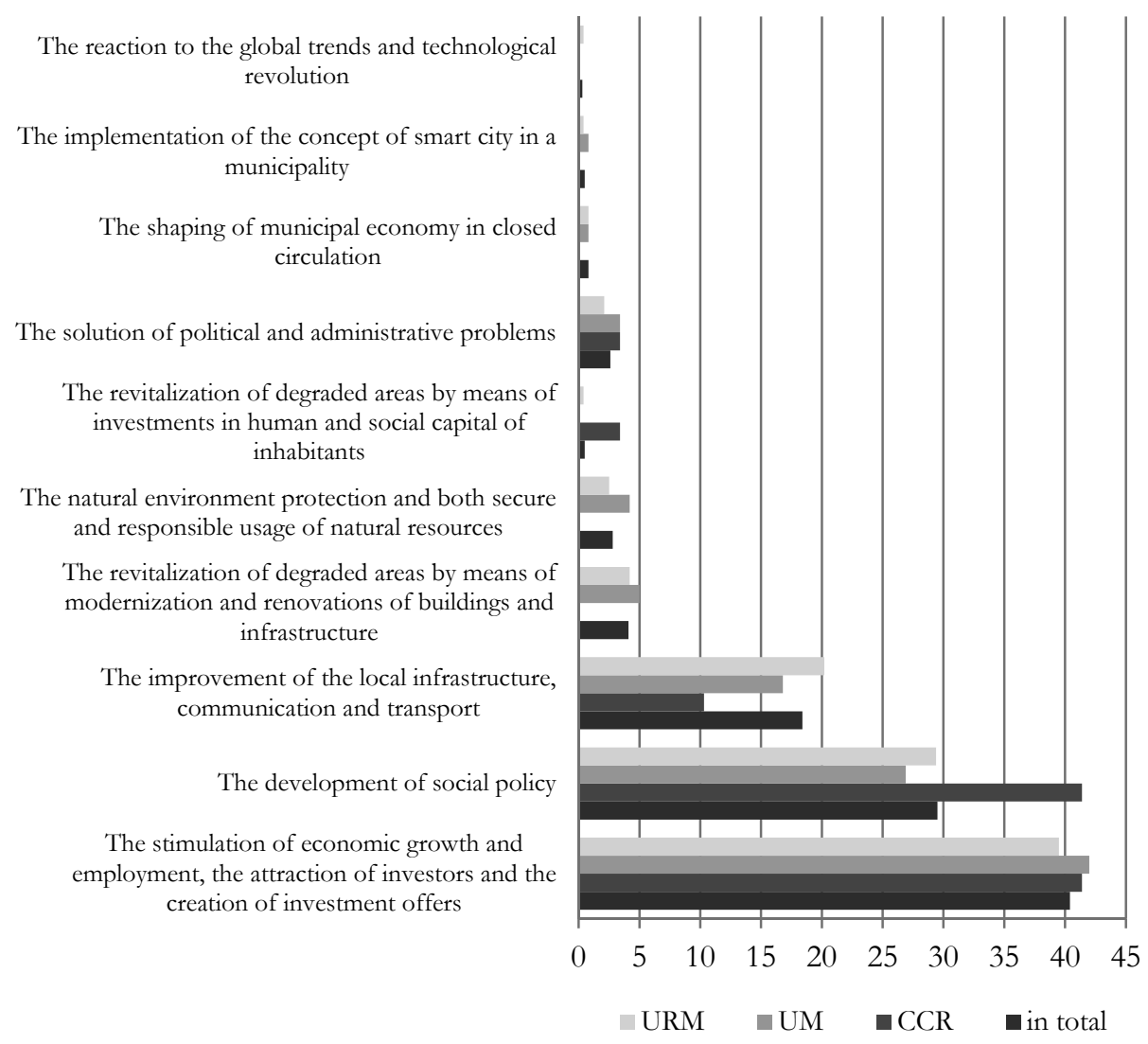

Source: own elaboration.

The ranking of development priorities in accordance with the municipality types ensure a slightly different perspective (chart 3). In particular, it can be observed that mostly in cities with county rights, the presidents who considered a social policy as the main challenge for development listed the stimulation of economic growth as the second main challenge. Additionally, the priority of social development is reinforced by the observation of the challenge in the revitalization of degraded areas by means of making investments in the human and social capital of inhabitants - the presidents of these cities mentioned these more frequently than the leaders of other units. One may assume that the leaders of these cities appreciate the importance of human and social capital for the activation of development processes. 
In the case of urban and both urban and rural municipalities a similar sequence of priorities may be observed. The leaders of both urban and rural municipalities morefrequently considered infrastructure development as the most important priority, which may be explained by smaller prosperity and a lower rate at which infrastructure investments are realized in such municipalities.

In the conditions of national, European or even global competition as well as due to the role of a territory in creating competitive advantages confirmed in the literature [Jacobs, 2000], one may not be surprised by such a noticeable concentration of politicians on economic issues and by making cities more attractive for starting an economic activity there. The views of Polish mayors on this matter do not differ from the opinions of local leaders in other European countries. The European mayors feel responsible for the mobilization of those resources that are necessary for facing the global competition and ensuring local development [Magnier et al. 2006, pp. 201-219] while their political priorities are concentrated on the development of entrepreneurship [Cabria et al., 2018, pp. 246-248].

The ensuring of material infrastructure is the main condition for the efficient realization of the strategy of attracting economic investment (but it is not enough to guarantee development). Therefore, most respondents in Poland considered it as the crucial challenge. Giving preferences to infrastructural priorities by the authorities of Polish municipalities were observed also in the earlier research conducted by the Foundation in Support of Local Democracy (Fundacja Rozwoju Demokracji Lokalnej) [Trutkowski, 2016, p. 34]. In Polish cities there still remains the need to develop infrastructure, especially in smaller cities with less opportunity to make up for the lack of this element from the European funds than it was the case in big cities [Churski, 2014, 31-32; Nowak, 2016, p. 128]. It explains the highest position of the priority connected with the development of infrastructure in our ranking in case of both urban and rural municipalities.

Good grades awarded by Polish mayors to a social policy are a sign of particular interest that urban leaders declare as regards the needs of city inhabitants, their standards of living and the combat with social inequalities. This observation confirms the validity of the orientation of Polish urban policy towards the revitalization of degraded urban areas which, in accordance with the current legislation, ought to be concentrated mainly on solving social problems in these spheres. The demographic trends also constitute the condition of the priority treatment of social policy at the local level. Extremely high marks for social policy in our research were not confirmed in the aforementioned FRDL research from the years 2010-2014 [Trutkowski, 2016, p. 48]. The observed clear change in the way urban leaders perceive social challenges is a positive sign of the transformation of local systems of the values presented by urban authorities with the orientation at solidarity and social justice.

Low evaluations regarding the importance of priorities such as the implementation of smart solutions, the reaction to the technological revolution and the integration of minorities do not correspond to the considerable importance of these aspects in shaping the image of a modern and tolerant city as well as with the needs 
in this sphere. Most likely, the underestimation in the importance of the integration of minorities results from the fact that cultural or religious diversity is perceived rather as a social problem than as the source of competitive advantages and the advantage of cities [Cabria et al., 2018, p. 247]. The critical evaluations ought to be formulated also as regards to the marks for environmental challenges. Such poor results are surprising in the situation of serious air pollution and decreasing natural resources in Polish cities and confirm that the political climate is not favorable for the implementation of the concept of ecological cities.

\section{Conclusions}

The present development challenges of Polish cities constitute the composition of civilization, social, economic and technological transformations and processes. The analysis included in this paper enables the formulation of the statement that cities must face the consequences of depopulation and both decreasing numbers and ageing process of their inhabitants, the elimination of social imbalances, the revitalization of degraded suburbs, the air pollution, global economic competition and creation of conditions (including the development of material equipment and the reinforcement of the potential of human capital or taking advantage of the merits of its diversity) and the image of cities with a high living standard.

The confrontation of these challenges with the development priorities adopted by the mayors and presidents of Polish cities makes it possible to draw several conclusions. Firstly, attention needs to be drawn to the considerable focus which city leaders pay to the hard and traditional aspects of local development. Mayors are clearly almost unaware of the necessity to take into consideration the assumptions of sustainable development in the urban policy. It needs emphasizing that while making evaluations mayors notice the postulates of sustainable development addressed at economy, society and environment, but considerably underestimate the environmental issues. The latest development challenges connected with the technological revolution and urban intelligence, the management of ethnic and cultural diversity, the revitalization of city centers and the implementation of the solutions of circular economics do not become the majors' priorities in development. These conclusions enabled the positive verification of our research hypothesis.

The largest disproportions between the weight of the priority given by mayors and the real challenges in the light of the presented research results occur with reference to the phenomenon of immigration and the interrelated need of the integration of minorities in urban communities. The consequences of the dynamic increase in the number of immigrants in Poland were not analyzed to a satisfactory degree even by the presidents of the largest cities. It may be considered as a very large hazard to the social cohesion of urban communities and efficient inclusion. A clear dissonance between the real problems and the declarations is observed as regards revitalization and its social dimension in particular. The latest global trends in city development such as smart or ecological cities are not particularly attractive 
for Polish authorities and do not become important development priorities. Concluding, Polish mayors still fail to observe the importance of the latest civilization, social or environmental challenges. They concentrate chiefly on the support for the development of domestic factors (economy, infrastructure, societies and, to a smaller degree, the natural environment resources), but do not display the orientation and opening to the outside world and the proactive approach to the challenges of the present day.

\section{References}

Cabria M., Magnier A., Pereira P., 2018, Mayors' agendas: emerging variations on the theme of entrepreneurialism, [in:] The European Mayor II. Political leaders in the changing context of local democracy, Heinelt H., Magnier A., Cabria M., Reynaert H. (eds.), Palgrave Macmillan, London.

Churski P., 2014, Wplyw fundusay Unii Europejskiej na rozwój Poznnania na tle wybranych miast w Polsce - próba bilansu piernszej dekady czronkostwa w Unii Europejskiej, „Rozwój regionalny i polityka regionalna”, $\mathrm{nr} 27$.

Dane statystyczne z zakeresu rewitalizacji na poziomie gmin, 2017, Urząd Statystyczny we Wrocławiu, Wrocław.

Haase A., 2013, No one-size-fits-all. O ró̈̇norodności kurczacych sie miast w Europie, [w:] Zarzadzanie rozwojem miast o zmniejszajacej sie licz̧bie mieszleańcón (w kontekśscie perspektymy finansowej 2014-2020), Domański B. (red.), Kancelaria Senatu, Warszawa.

Jacobs J., 2000, The Nature of Economies, Vintage Books, New York.

Krajowa Polityka Miejska 2023, 2015, Ministerstwo Inwestycji i Rozwoju, Warszawa.

Magnier A., Navarro C., Russo P., 2006, Urban Systems as Growth Machines? Mayors' Governing Networks Against Global Indeterminacy, [in:] The European Mayor - Political Leaders in the Changing Context of Local Democracy, Bäck H., Heinelt H., Magnier A. (eds.), Springer Verlag, Wiesbaden.

Marks-Bielska R., Lizińska W., Babuchowska K., Wojarska M., 2017, Raport z. uykonania projektu badawczego Sprawnośc instytucjonalna vs. lokalny rozwój gospodarczy csynniki ksztattujace $i$ interakcje, Uniwersytet Warmińsko-Mazurski w Olsztynie, Olsztyn.

Meadowcroft J., Farrell K.N., Spangenberg J., 2005, Developing a framework for sustainability governance in the EU, "International Journal of Sustainable Development", vol. 8, no. 1/2, pp. 3-11, DOI: 10.1504/IJSD.2005.007371.

Mendizabala M., Heidrichb O., Feliua E., García-Blancoa G., Mendizabal A., 2018, Stimulating urban transition and transformation to achieve sustainable and resilient cities, "Renewable and Sustainable Energy Reviews", vol. 94, pp. 410-418, DOI: 10. 1016/j.rser.2018.06.003.

New Urban Agenda, 2017, United Nations Habitat III Conference, United Nation.

Nowak A., 2016, Rola środków unijnych udostepnionych w ramach Programu Operacyjnego Infrastruktura i Środowisko w rozwoju spoteczno-gospodarcaym podregionów w Polsce, „Rozwój Regionalny i Polityka Regionalna", nr 33, s. 117-137. 
Nowe priorytety rzqdowej polityki migracyjnej, 2018, Ministerstwo Inwestycji i Rozwoju, Warszawa, https://www.miir.gov.pl/strony/aktualnosci/nowe-priorytety-rzadowej-polityki-migracyjnej [date of entry: 04.11.2018].

Podgórniak-Krzykacz A., 2016, Local governance, cayli jak rónnowaşyó zarzadzanie miastem, [w:] EkoMiasto\#Zarzadzanie. Zrównoważony, inteligentny i partycypacyjny rozuóój miast, Przygodzki Z. (red.), Wydawnictwo Uniwersytetu Lódzkiego, Łódź.

Przywojska J., 2016, Rewitalizacja miast aspekt spoteczny, Wydawnictwo Uniwersytetu Łódzkiego, Łódź.

Rocżik demograficzny, 2018, Główny Urząd Statystyczny, Warszawa.

Różne oblicza ubóstwa w Polsce w 2015 r. i 2018 r. na podstawie Badania spójności spotecznej, 2018, Główny Urząd Statystyczny, Warszawa.

Sáez L., Periáñez I., Heras-Saizarbitoria I., 2017, Measuring urban competitiveness: ranking European large urban zones, "Journal of Place Management and Development", vol. 10, no. 5, pp. 479-496, DOI: 10.1108/JPMD-07-2017-0066.

Sikora-Fernandez D., 2018, Smarter cities in post-socialist country: Example of Poland, “Cities", vol. 78, pp. 52-59, DOI: 10.1016/j.cities.2018.03.01.

Śleszyński P., 2018, Demograficzne myzwania rožoju regionalnego Polski, „Studia Komitetu Przestrzennego Zagospodarowania Kraju”, nr 183, s. 225-247.

Szczech-Pietkiewicz E., 2012, Konkurencyjnośc mybranych polskich miast na tle miast $z$ innych państw cžtonkowskich Unii Europejskiej, „Zeszyty Naukowe. Szkoła Główna Handlowa. Kolegium Gospodarki Światowej”, nr 34, s. 128-150.

Trutkowski C., 2016, Skutecziny urz̨ad samorz̨adowy. Rozwój kompetencii kadr jako element budowy sprawnej administraci lokalnej, Fundacja Rozwoju Demokracji Lokalnej, Warszawa.

www 1, https://ec.europa.eu/eurostat/tgm/table.do?tab=table\&init=1\&language= en\&pcode=sdg_11_50\&plugin $=1$ [date of entry: 20.03.2019].

www 2, https://www.eea.europa.eu/themes/air/country-fact-sheets/poland [date of entry: 20.03.2019]. 